\title{
Indicatieve planning als beleidsinstrument van de industrialisatiepolitiek in de jaren vijftig
}

\author{
J.R.M. VAN DEN BRINK
}

De uitvoerige aandacht, die Griffiths aan mijn boek heeft besteed, stel ik zeer op prijs. In het bijzonder het deel van zijn artikel dat handelt over de eerste industrialisatienota's heb ik met belangstelling gelezen; daarin wordt naar een zakelijke onderbouwing van het gegeven (negatieve) oordeel gestreefd. Van mijn kant zal ik er gaarne wat uitvoeriger op in gaan. Voor het overige wil ik kort zijn.

Een ding is duidelijk, ik heb Griffiths geërgerd, allereerst met de opzet en bedoeling van mijn boek. Het boek is inderdaad geen poging tot geschiedschrijving en het is ook geen bundeling van memoires; het

wil gesprekstof leveren voor de maatschappelijke discussie in een vrij land: een driestromenland, waarin socialisme, liberalisme en de christen-democratie het sociale en politieke denken bepalen...Het boek is geschreven vanuit een christen-democratische levensvisie...Het richt zich vooral tot liberalen en socialisten met de nadruk op de laatsten. Vooral zij - orthodoxe en neo-marxisten, maar ook democratisch-socialisten - hebben de laatste halve eeuw, aan beide kanten van het IJzeren Gordijn, hun stempel op de samenleving gedrukt. De wat eenzijdige accenten in dit boek zijn danook een poging tot efficiency1.

Inderdaad, 'zo'n boek is het'; wie van 'zo'n boek' niet houdt, moet het ongelezen laten. Het biedt namelijk niet meer, maar ook niet minder dan het belooft. Overigens, het is mij opgevallen, dat juist veel 'linkse' commentatoren de opzet van het boek waarderen en het niet als warrige nonsens afdoen.

Zoeken naar een heilstaat gaat over politieke economie en economische politiek; het streven van mensen, met zeer uiteenlopende denkbeelden en belangen, en levend in zeer uiteenlopende economische systemen, naar een zowel (economisch) doelmatige als rechtvaardige samenleving. Dat streven wordt vooral op zijn resultaten beoordeeld. De 'uitstapjes naar socialistische en nietsocialistische Europese economieën' bedoelen danook iets meer dan 'uitstapjes' te zijn, al is het moeilijk - bij de beoordeling van de resultaten van een bepaalde economische politiek of van een bepaald economisch systeem - de aan die politiek gebonden en de systeemgebonden gevolgen van de overige te scheiden. Toch leek de poging mij de moeite waard. Wij zijn vandaag welhaast vergeten, dat in Nederland in de jaren zeventig bijvoorbeeld het Joegoslavische economische systeem door velen serieus als een goede oplossing voor onze problemen werd beschouwd.

Griffiths is van mening dat ik in de polemische passages van het boek tegenstanders 'meedogenloos' vervolg, tracht te 'ontmaskeren' en 'bespot'. Als dat zo is: ik heb het niet bedoeld; het ligt niet in mijn aard, en ik ben niet opgegroeid in een tijdperk waarin het kwetsen van tegenstanders door sommigen publiekelijk wordt geprezen.

Wanneer ik over Griffiths' kennelijke irritatie en emotionaliteit over sommige passages in mijn boek, waarin wordt geredetwist met opponenten, nog eens nadenk, dan voel ik de behoefte aan twee opmerkingen. De eerste is gegoten in de vorm van een vraag.

Hebben de historici zich wel eens systematisch verdiept in de verbale vorm waarin de kritiek op de christen-democratie tijdens de polarisatieperiode na het tweede Vaticaans concilie gestalte kreeg, en met name door sommige 'linkse' opponenten - in de wereld van de politiek, de vakbeweging en de politieke economie - werd gegoten? Maar zelfs als hun research het antwoord: 'bar en boos', zou opleveren - ik geef het toe - vormt dit geen excuus voor onhoffelijk welvaartsstaat (Amsterdam-Brussel, 1984) voorwoord, 8. 
gedrag, laat staan voor een onchristelijke reactie mijnerzijds; hoogstens wordt deze laatste indien ik hier terecht van word beschuldigd - er wat begrijpelijker door. De lezer oordele zelf.

De tweede opmerking is een advies. De betekenis van mijn boek in het historische vlak moet naar mijn mening vooral in het simpele feit worden gezocht, dat het werd geschreven. De vond het namelijk een zwaar karwei. Het bewijst daardoor met welk een opgekropt gemoed mensen als ik - die hun leven lang met economische problemen bezig waren en er grote verantwoordelijkheid voor droegen - tegen het eind van de jaren zeventig in Nederland aan hun gepensioneerde bestaan begonnen; een levensfase waarin het voor iedere bestuurder wat gemakkelijker wordt om vrijuit te spreken.

Tot op zekere hoogte - en vooral als historisch verschijnsel - is er overeenkomst tussen het schrijven van mijn boek en het publieke optreden van bijvoorbeeld Wagner in het belang van de herindustrialisatie van Nederland, na zijn terugtreden als president-directeur van de Koninklijke. Het is danook geen toeval, dat wij beiden tot de ondertekenaars van de brief van de negen uit januari 1976 behoren.

Wat de periode betreft, die door de eerste drie industrialisatienota's wordt bestreken - 19481952, de tijd van mijn ministerschap — stelt Griffiths vast dat ik 'relatief weinig aandacht' aan mijn ministeriële loopbaan heb besteed, terwijl veel op 'direct voorhanden secundaire bronnen' is gebaseerd. Beide constateringen zijn juist en hangen met de al gereleveerde aard van het boek samen. Dat mijn weergave van deze jaren daardoor eerder een bestendiging zou zijn van 'de vele mythes die de periode omringen dan dat die werden tenietgedaan' ben ik niet met hem eens. Ik heb namelijk geprobeerd de periode zo zuiver en zo duidelijk mogelijk weer te geven, al ben ik in dit laatste kennelijk niet geslaagd. De wens om een zo zuiver mogelijke beschrijving te geven was voor mij aanleiding de concepttekst van dit gedeelte ter kritische beoordeling onder anderen aan A. Winsemius toe te zenden - de eerste directeur-generaal voor de industrialisatie die zo vriendelijk was zich zeer zorgvuldig van die taak te kwijten.

Mijn moeilijkheid bij de behandeling van Griffiths' beschouwingen over de eerste industrialisatienota's en met name over de opbouw van het cijfermateriaal en de aard en betekenis van een industrialisatieschema - een indicatief plan - voor een markteconomie in het algemeen, is, dat ik het er in grote trekken mee eens ben, maar dat ik toch van mening ben, dat de wezenlijke betekenis van deze industrialisatienota's in dat tijdsgewricht hem is ontgaan; hij heeft haar niet begrepen, niet echt 'geproefd', zelfs nauwelijks aangeraakt. De eerste industrialisatienota's zijn namelijk - in eerste instantie - vooral beleidsinstrumenten die het mogelijk maakten het vertrouwen van het bedrijfsleven - met name van de ondernemers - in het gevoerde en te voeren economisch beleid en de gestelde beleidsdoeleinden te winnen, zonder het vertrouwen van de werknemers, de vakbonden en de sociaal-democratische coalitiepartner voor een belangrijk deel of volledig te verspelen; iets wat in ons economische systeem van zeer grote betekenis is. Ook in een periode als de naoorlogse, waarin de bereidheid tot samenwerking groter was dan thans, kan zich gemakkelijk een vertrouwenskloof ontwikkelen - vooral in een moeilijke overgangsperiode - zoals de sociaal-economische geschiedenis van Groot-Brittannië aantoont.

Vanaf de bevrijding tot de vorming van de regering-Beel in juli 1946, was het met het vertrouwen van de ondernemers in de beleidsvoornemens van de regering slecht gesteld, ook al kon dit gebrek aan vertrouwen voorlopig weinig kwaad, aangezien de schaarste-economie nauwelijks enige ruimte voor ondernemersinitiatieven liet. Het is de tijd van minister Vos: een voorontwerp van wet op de Publiekrechtelijke Bedrijfsorganisatie, gebaseerd op organisatiedwang, dat door de ondernemers (terecht) als een poging tot invoering van een Nederlandse vorm van socialisme werd gezien; ministeriële denkbeelden over gedetailleerde dirigerende en taakstellende economische planning - 'geleide economie' - ook in normale tijden. En een ambtelijk onderzoek naar de mogelijkheid van invoering van een produktiewet die de ondernemers — als blijvend instrument van economische politiek - 'produktieplicht' wil opleggen 2.

2. P.E. de Hen, Actieve en re-actieve industriepolitiek in Nederland (Amsterdam, 1980) 259-273; Van den Brink, Zoeken naar een 'heilstaat', 437-440. 


\section{J.R.M. VAN DEN BRINK}

Intussen is minister Huysmans aan het werk gegaan. Hij heeft de top van het ministerie van economische zaken ingrijpend gewijzigd en zich duidelijk tegen 'geleide economie' als permanent systeem van economische politiek uitgesproken. In de loop van 1947 wordt de minister ernstig ziek en is hij niet meer in staat zijn ambt uit te oefenen. Drie weken na de beëdiging van ondergetekende als zijn opvolger (21 januari 1948) sta ik in de Tweede Kamer (10, 11 en 12 februari) om Huysmans' begroting-1948 te verdedigen. Ik word er met scherpe kritiek van de grote coalitiepartner - de PvdA - geconfronteerd: Nederhorst dringt op een permanent systeem van 'geleide economie' aan, op invoering van een produktiewet en op de opstelling van een industrialisatieschema; zijn collega Suurhoff houdt een zeer principieel pleidooi voor 'geleide economie', dirigerende planning en socialisatie. Wanneer Suurhoff zijn argumenten voor socialisatie aandraagt, staan de particuliere kolenmijnen in Limburg onder beheer, daterend uit de tijd van de bevrijding (KB van 26 april 1945). Philips heeft - indien ik mij dit goed herinner dan de beschikking over een krediet van de staat in de orde van grootte van ruim $f 100$ miljoen, een voor die tijd zeer fors bedrag. De onderneming heeft daartegenover de aanwijzing van een 'regeringscommissaris' moeten accepteren. Hij heet Tjardus Greidanus, en is een geharnast monetarist 'avant la lettre', een onverdacht voorstander van de ondernemingsgewijze organisatie van de voortbrenging en firmant van Pierson; hij kreeg vóór de oorlog bekendheid als bestrijder van de 'nieuwlichterij' van Keynes. Maar toch... het bloed kruipt waar het niet gaan kan. Ondanks de (poging tot) doorbraak van de - eerst enkele jaren oude - Partij van de Arbeid, is er een stroming van oud-SDAPers in die partij, die krachtig op socialisatie aandringt. Het beheer over de particuliere mijnen betekent voor hen een 'vette kluif', die zij niet los willen laten, en die de eetlust heeft opgewekt.

Het korte optreden van Huysmans heeft stellig het vertrouwen van de ondernemers in het voorgenomen economische beleid aanzienlijk vergroot, maar het vertrouwen van de grote coalitiepartner blijkt ernstig te zijn aangetast; er is sprake van een levensgroot onbehagen. Het lijkt zaak aan de verlangens van de PvdA tegemoet te komen, overal waar dat maar enigszins kan. Helaas botsen de op hoge toon uitgesproken socialistische wensen op bijna alle punten zeer wezenlijk met de economische politiek die ik denk te voeren. Alleen de denkbeelden over de opstelling van een industrialisatieschema spreken mij aan; zij passen in de nog vage plannen voor een systematische, actieve en mobiliserende industrialisatiepolitiek, waarmee ik rondloop; mits het schema niet als een dirigerend plan, maar als een met zorg uitgestippelde - mogelijke - marsroute wordt opgevat, een instrument van indicatieve planning. Toch durf ik in het februari-debat nog geen concrete toezeggingen te doen; daarvoor is onder andere de deviezenpositie te wankel, ondanks de verhoopte en onverwachte Marshallhulp. Nederhorsts suggestie, om dan maar 'alternatieve industrialisatieschema's' op te stellen, lokt mij in het geheel niet aan. Dat loopt op academische vingeroefeningen uit, waarmee geen enkel praktisch belang is gediend, maar die wel veel tijd en energie zullen kosten. Bovendien, ik heb in die tijd vrijwel al mijn tijd en energie voor iets anders nodig: het voorkomen van een drastische verlaging van het invoer-, produktie- en voorzieningenniveau, in het aangezicht van de Marshallhulp.

Wanneer ik in november 1948 de begroting-1949 van het ministerie van economische zaken in de Tweede Kamer verdedig, sta ik - in meerdere opzichten - steviger op het ijs. De Marshall hulp is intussen een vaststaand feit geworden; er is meer zekerheid over de deviezenpositie en over een houdbaar industrieel investeringsniveau; op het departement ben ik bezig met een grondige reorganisatie van dat deel van het apparaat dat mijn industrialisatiepolitiek zal moeten realiseren. Indien ik mij goed herinner heb ik dan al in de troonrede (van Prinsjesdag 1948) de aankondiging van een directoraat-generaal voor de industrialisatie doen opnemen. En in de memorie van antwoord op het voorlopig verslag naar aanleiding van de begroting-1949 heb ik de opstelling van een industrialisatieschema al toegezegd. Ik heb in die tijd aanzienlijk concretere denkbeelden over de vraag hoe ik de industrialisatiepolitiek - in al haar facetten - systematisch wil aanpakken. Op 7 februari 1949 wordt het directoraat-generaal voor de industrialisatie opgericht en gaat Winsemius met zijn mensen aan de slag. Een half jaar later is de eerste indus- 
trialisatienota gereed; zij wordt in september 1949, als bijlage IV, bij de begroting-1950 van het ministerie van economische zaken gevoegd.

'Waarom zo laat'? Omdat lange tijd onvoldoende zekerheid bestond over een houdbaar en haalbaar industrieel investeringsniveau. Omdat niet eerder over een apparaat werd beschikt, dat - althans in mijn ogen - in staat zou zijn de 'follow up' van de te publiceren industrialisatienota's effectief te verzorgen. Gebrek aan 'follow up' zou voor het welslagen van de voorgenomen industrialisatiepolitiek desastreus zijn geweest. Omdat intussen, in interdepartementaal verband, pogingen werden ondernomen om een aantal materiële beleidsinstrumenten te creëren waaronder enkele van Fiscale aard - die het mogelijk zouden moeten maken om de in de nota genoemde industrialisatiedoeleinden op het aangegeven tijdstip te realiseren. De invoering van een fiscaal systeem van vervroegde en versnelde afschrijving was er één van; het kon helaas eerst in de tweede industrialisatienota worden opgenomen, hoewel ook in de eerste al op een zekere verruiming van bepaalde fiscale afschrijvingsmogelijkheden kon worden gewezen.

Een belangrijk concreet punt van kritiek van Griffiths op de industrialisatienota's als instrumenten van economische politiek — zoals hij die ziet - is in zijn stelling vervat, dat

niemand tot op heden heeft kunnen aantonen dat ondernemers hun investerings- of werkgelegenheidspatroon wijzigen om in te passen in wat plannenmakers menen dat nodig is om de naar hun zeggen diep gewortelde structurele problemen in de economie op te lossen... het beleid zélf is belangrijk en niet de vorm waarin het wordt gepopulariseerd.

Met het eerste deel van deze uitspraak trapt hij bij mij een open deur in. Mijn beleid als minister, mijn ervaringen als ondernemer-bankier en mijn bedoelingen (en teksten) als auteur gaan alle van dezelfde grondgedachte uit of bevestigen haar. Want ondernemen is ook in mijn ogen anticiperen op een onzekere toekomst, verkennen van (onzekere) mogelijkheden die alleen door de (veranderende) markt worden gedicteerd, in vrijheid en onder eigen verantwoordelijkheid binnen door de overheid gecreëerde beleidskaders - op basis van een, zo zorgvuldig mogelijk uitgevoerde, kosten/opbrengsten vergelijking. Daarom: ruimte voor marktconform gedrag, ruimte voor ondernemersinitiatief, stimulering van de ondernemingsgeest en -lust, en het onderbouwen van de winstverwachtingen van de ondernemers door een realistische - gediversifieerde - economische politiek. Ook naar mijn mening vormen de punten van materieel beleid en de gebeurtenissen en omstandigheden op economisch gebied, die Griffiths aan het eind van zijn artikel opsomt 'overtuigender oorzaken' voor het naoorlogse economische herstel dan de publikatie van de industrialisatienota's, zoals trouwens ook de beschrijving en analyse van de meeste van deze punten en gebeurtenissen in mijn boek aantoont. Maar er is - vooral in de eerste jaren na de bevrijding - wel een heel duidelijke wisselwerking tussen de consistentie en effectiviteit van het materiële beleid en de wijze waarop het wordt gepresenteerd.

Ook de vorm waarin een beleid wordt 'gepopulariseerd', dat wil zeggen overgebracht aan al degenen die het aangaat (medewerkers, andere departementen, politieke 'tegenspelers' en ieder ander die ermee in aanraking komt) is altijd belangrijk maar soms van uitzonderlijk belang. Dat laatste was naar mijn mening in de eerste jaren na de oorlog stellig het geval. Er bestond in die tijd een duidelijke behoefte om het 'sociaal-veeleisende' economische beleid - dat onder andere een lang vol te houden consumptiebeperking inhield - op een tot dan toe onbekende wijze over het voetlicht te brengen; als het ware via de 'versterkte zender'. En in een vorm waarin ook 'links' Nederland zich zoveel mogelijk zou kunnen herkennen. En waarin de sociaal-democratische verlangens - voor zover maar enigszins mogelijk - ook materieel zouden worden gehonoreerd. Dat. laatste was temeer noodzakelijk, omdat in de eerste industrialisatienota heel wat beleidsvoornemens moesten worden aangekondigd die in 'links' Nederland gevoelig lagen, zoals: consumptiebeperking in een tijd, waarin de reële welvaart van de minst draagkrachtigen minder dan eenderde van thans bedroeg, een goed-rendabel bedrijfsleven, economische liberalisatie (deregulering), loondifferentiatie (denivellering), stimulering van ploegenarbeid, handhaving van een redelijke arbeidsreserve - een werkloosheid van gemiddeld $3 \%$ van de afhankelijke beroepsbevol- 


\section{J.R.M. VAN DEN BRINK}

king (ter voorkoming van verstarring op de arbeidsmarkt) — en massale technische, industriegerichte, opleidingen van jeugdigen.

De reactie van de PvdA op de begroting-1949 van economische zaken was - zoals ik had gehoopt - gematigd. De aankondiging van een directoraat-generaal voor de industrialisatie en van een industrialisatieschema waren kennelijk in goede aarde gevallen. De toon van Vos' redevoering in de Tweede Kamer als woordvoerder van de PvdA in november 1949 was bijna welwillend, al behield hij zijn twijfels over mijn beleid:

het is meer en meer mijn overtuiging, Mijnheer de Voorzitter, gegrond op waarneming en analyse van de maatschappij, dat het 'vrije spel der maatschappelijke krachten', en daartoe dient men zeker de concurrentie te rekenen, slechts binnen een steeds nauwere marge nuttig kan werken... Mede daarom moge ik adviseren niet te veel te vertrouwen op het automatisme van de concurrentie. Liever stel ik mijn vertrouwen in een ordening met een behoorlijke mate van overheidsinvloed3.

Merkwaardig genoeg drong ook de woordvoerder van de liberalen, Zegering Hadders, op de invoering van een 'industrialisatieplan' aan! Maar dan wel om tijdgebonden redenen. Wij leven dan nog in de naoorlogse schaarste-economie met haar beperkingen, toewijzingen en (bedrijfs)vergunningen; de ondernemers willen kennelijk weten waar zij an toe zijn: 'Het bedrijfsleven heeft herhaaldelijk gevraagd om publicatie van richtlijnen, opdat het een soort terreinafbakening heeft, indien het zijn plannen gaat uitwerken'4.

Om overspannen verwachtingen te voorkomen probeer ik al in dit november-debat de betekenis van het op te stellen industrialisatieschema te relativeren:

... onze industrialisatie (zal) niet tot stand komen door het schema. Ik heb er in de Memorie van Antwoord nadrukkelijk op gewezen, dat industrialisatie de vrucht is van economische beslissingen...: men weegt de offers af tegenover de verwachte opbrengst... tenslotte is het besluit tot investeren een economische beslissing, waarbij hard, keihard moet worden gerekend5.

In de, tien maanden later verschijnende, eerste industrialisatienota wordt de relativering van het schema nog eens herhaald. Daartoe is temeer aanleiding, daar intussen de ruimte voor ondememersinitiatieven aanzienlijk is toegenomen als gevolg van de liberalisatiepolitiek en de stijgende produktie:

Ondergetekende heeft reeds bij de schriftelijke en mondelinge behandeling van de begroting 1949 gewaarschuwd tegen overschatting van de betekenis van een dergelijk schema. Hij moge deze waarschuwing hier herhalen.

Het schema mag alleen worden gehanteerd 'als achtergrond, waartegen de werkelijke ontwikkeling zich voltrekt6.

In mijn boek heb ik geen ander beeld willen schetsen. Enkele, in dit verband relevante, passages uit de eerste industrialisatienota heb ik danook letterlijk overgenomen, onder andere die over het 'achtergrondkarakter' van het industrialisatieschema. Dit laatste wordt als niet méér dan een vorm van 'indicatieve planning, een economische prognose, op basis van een ontwikkelingsscenario, planning van de economische politiek', beschouwd7.

Een tweede concreet bezwaar van Griffiths betreft de 'originaliteit' van de gevoerde industrialisatiepolitiek. Ik zou 'stilzwijgend' suggereren dat 'mijn industrialisatiepolitiek' een eigen ontwerp was (hoewel ik haar in mijn boek in feite 'een voortzetting van het industriebeleid van vóór de

3. Handelingen van de Staten-Generaal, Tweede Kamer, Verslag 1-283, 1948-1949, 429.

4. Ibidem, 433 .

5. Ibidem, 466 .

6. Nota inzake de industrialisatie van Nederland, overdruk van: Bijlage IV, Memorie van toelichting op het

Xe hoofdstuk (economische zaken) van de rijksbegroting voor het dienstjaar 1950 (Den Haag, september 1949)

4.

7. Van den Brink, Zoeken naar een 'heilstaat', 443, 444. 
oorlog' noem, zij het met een 'eigen karakter'8). De oorspronkelijkheid van, met name, de industrialisatienota's als instrumenten van economische politiek zat niet in de aard en oorspronkelijkheid van het gepresenteerde cijfermateriaal of in de inhoud van de aangekondigde beleidsmaatregelen - ieder op zichzelf beschouwd - maar in de presentatie van een veelomvattend, samenhangend, in de tijd gepland, geheel van doeleinden en middelen op het gebied van de industrialisatie. Onmiskenbaar nieuw was het loutere feit, dat er industrialisatienota's werden geschreven, dat zij met grote regelmaat verschenen - althans in de eerste jaren - en dat de erin aangekondigde beleidsmaatregelen als regel snel werden geëffectueerd.

De in de nota's gehanteerde cijfers werden noch door mij, noch door mijn medewerkers uit de hoge hoed getoverd; er werden geen auteursrechten voor opgeëist. Wel werd zo zorgvuldig mogelijk op het beschikbare cijfermateriaal voortgebouwd; in de eerste plaats op de cijfers en gegevens waarover het nieuwe directoraat-generaal voor de industrialisatie zelf beschikte (men vergete niet, dat het directoraat industrialisatie van 'handel en nijverheid' in februari 1949 in het nieuwe organisatorische complex was opgegaan).

De uitvoerige vergelijking van gegevens uit de eerste industrialisatienota met de inhoud van het industrialisatieschema dat in januari 1948 - bij de tweede Nederlandse leningaanvraag aan de Internationale Bank voor Herstel en Ontwikkeling - werd overlegd, heeft mij danook niet geschokt of zelfs maar verrast. Het spreekt wel vanzelf dat mijn medewerkers bij de uitvoering van hun opdracht alle cijfers gebruikten die zij in een eerder stadium - zij het voor andere doeleinden - zelf hadden verzameld, respectievelijk hadden gecoördineerd. De overigens interessante, vergelijking van Griffiths toont aan - en dat is belangrijk - dat de Nederlandse regering, ook in de eerste onoverzichtelijke jaren na de oorlog, bij het verstrekken van belangrijke economische informatie consistent te werk ging; aan verschillende loketten werd over dezelfde materie geen wezenlijk verschillende informatie gegeven.

Voor het materiaal dat door het 'bureau Hirschfeld' werd verzameld voor de American Economie Cooperation Administration, geldt naar mijn mening hetzelfde. Bij het opbouwen en verzamelen van al die gegevens bestond er in die tijd tussen de diverse ambtelijke staven - die als regel niet zeer groot waren - een redelijk goed contact en een vruchtbare wisselwerking. Er werd van eikaars gegevens gebruik gemaakt. Niet iedere ambtenaar was er op uit — of zag zich gedwongen - 'het wiel zelf nog weer eens uit te vinden'.

Wanneer ik tijdens het schrijven van mijn boek het door Griffiths genoemde document voor ogen zou hebben gehad, zou ik het overigens zeker hebben genoemd als een industrieel schema dat al in de periode-Huysmans in de industrialisatiesector van het ministerie van economische zaken ontstond. Waar het mij bij de opbouw van het nieuwe directoraat-generaal echter vooral om ging, was niet zozeer een nieuw studieapparaat creëren dat knappe industrialisatieschema's zou kunnen ontwerpen - hoe belangrijk dat op zichzelf ook is - maar het starten van een kleine, overzichtelijke en beweeglijke, sterk praktijk gerichte, organisatie op hoog ambtelijk niveau - direct onder de minister - die in staat zou zijn een grote stootkracht te ontwikkelen op het terrein van de materiële industrialisatiepolitiek, zoals ik dat ook in mijn boek heb beschreven.

Met Griffiths' opmerking, dat het schema uit januari 1948 'veel vooruitziender', zo niet 'roekelozer', was dan het schema dat in de eerste industrialisatienota werd opgenomen, ben ik het eens. Maar hij ziet daarbij wel over het hoofd, dat er een groot verschil bestaat tussen het onderbouwen van een kredietaanvraag en het opstellen van een industrialisatieschema. Bij het onderbouwen van een kredietaanvraag is de aanvrager - zoals iedere bankier weet - tot een zeker optimisme geneigd, aangezien zijn prognose vooral is bedoeld om de kredietaanvraag aannemelijk te maken, en zij eerst kan worden getoetst wanneer het krediet allang gegeven is (zo er al van enige toetsing sprake zal zijn). Bij het opstellen van een industrialisatieschema gaat het om iets geheel anders; een bewindsman legt zich — bijvoorbeeld in 1949 - ten overstaan van het

\section{Ibidem, 445.}




\section{J.R.M. VAN DEN BRINK}

hele Nederlandse volk op een toekomstbeeld vast, waaraan hij meer dan vijfendertig jaar later nog wordt gehouden!

In mijn boek heb ik geprobeerd de belangrijkste veranderingen in de structuur (en de groei) van de Nederlandse economie gedurende de naoorlogse periode - voorzover zij niet rechtstreeks met de internationale conjunctuurontwikkeling samenhingen - te analyseren en te verklaren. Dat geldt ook voor de ontwikkeling en plaats van de industrie in ons maatschappelijk-economisch bestel, en voor de merkwaardige verschuivingen die zich bij de realisatie van de industrialisatieschema's - vooral wat de belangrijkste onderdelen en meetpunten betreft, zoals de absorptie van arbeidskrachten, de industriële investeringen en het herstel van betalingsbalansevenwicht - voordeden. Ook ga ik in op de strijd, die aan het begin van de Korea-crisis - in de zomer van 1950 - tussen voor- en tegenstanders van 'fysieke controles' (directe importbeheersing en deliberalisatie, herregulering) in de REA9 werd gevoerd10. Ik laat daarbij zien waarom mijn voorkeur sterk naar indirecte, monetaire en fiscale maatregelen uitging, onder handhaving van de bereikte vrijheid van invoer. En ik probeer duidelijk te maken, dat dit standpunt rechtstreeks uit mijn industrialisatiepolitiek en de zojuist gepubliceerde industrialisatiedoeleinden voortvloeide. Griffiths gaat aan dit alles vrijwel volledig voorbij. Hij komt niet verder dan het ietwat smalend toeschrijven van het overwinnen van de Korea-crisis en het ontstaan van het betalingsbalansoverschot in 1952 aan 'een flinke dosis neo-klassiek deflatiemedicijn'. De waarschijnlijk zeer beperkte omvang van de structurele component in het grote betalingsbalansoverschot van 1952 ad $13 / 4$ miljard gulden lijkt hem te ontgaan; hij beseft onvoldoende of niet, dat het inderdaad indrukwekkende overschot - zoals ik in mijn boek heb uiteengezet - niet veel meer was dan een reactie op de grote tekorten, die in 1950 en 1951 ontstonden, vooral als gevolg van de abnormaal grote (industriële) invoer door voorraadvorming. Daarnaast werd het beeld vertroebeld door een spectaculaire ruilvoetverslechtering in de industriële sector. Aldus komt Griffiths tot een weergave van de industriële ontwikkeling, die de werkelijkheid niet dekt.

Hij beperkt zich voor het overige tot een vergelijking van de industrialisatiedoeleinden en schema's met de werkelijkheid. En hij doet dat met de nauwgezetheid en strengheid van een goede accountant. Hij constateert: dat sommige doeleinden werden overtroffen en andere niet werden gehaald; dat sommige doeleinden redelijk werden gehaald, maar niet 'langs de door de beleidsontwerpers uitgestippelde route'; dat sommige doeleinden tussentijds werden aangepast in een vergevorderd stadium van de planperiode — zodat de realisatie niet meer dan 'een oefening in boekhouden' was; dat de mogelijkheid van een snelle industriële structuurverandering in de eerste industrialisatienota werd overschat.

Al deze constateringen zijn juist, zoals ook de opmerkingen van de meeste accountants als regel juist zijn - al worden ze door déze accountant soms wat denigrerend uitgesproken - maar niemand hoeft zich er voor te schamen; wanneer men althans bereid is het karakter van indicatieve planning in een snel liberaliserende markteconomie in de beschouwing te betrekken. Ik voel mij er niet door verrast, teleurgesteld of beschaamd. Bovendien, de latere beoordelaar is van meet af aan gewaarschuwd, want blijkens de eerste industrialisatienota 'mag men het schema...zeker niet opvatten als een star en onveranderlijk geheel. Voortdurende aanpassing en wijziging in verband met de loop der gebeurtenissen zal nodig zijn' 11 . Ook hier weer blijkt dat Griffiths geneigd is de onderzochte materie op een wat cerebrale en isolerende wijze te benaderen, waarbij hij ten onrechte de indruk wekt, dat ik de publikatie van het indicatieve industrialisatieschema als de kern van mijn industrialisatiebeleid zag, de echte locomotief van de feitelijke expansie van de industrie!

Wanneer ik Griffiths' beschouwingen in dit deel van zijn artikel op mij laat inwerken, dan betwijfel ik of hij ooit in aanraking kwam met de planning binnen een zeer grote onderneming. De moeilijkheden die daarbij worden ondervonden zijn niet wezenlijk verschillend van wat wij

9. Raad voor economische aangelegenheden (uit de ministerraad).

10. Van de Brink, Zoeken naar een 'heilstaat', 448-451.

11. Eerste industrialisatienota (zie noot 5) 4. 
rond 1950 op dit gebied op economische zaken meemaakten. Iedere ondernemer weet, dat vooral een operationeel meerjarenplan regelmatig moet worden bijgesteld; de meeste grote ondernemingen werken danook met voortschrijdende meerjarenplannen die - volgens vaste methodiek en in een vaste planningcyclus - van jaar tot jaar worden herzien. Toch zou ik Griffiths willen vragen, mij vandaag één 'captain of industry' te noemen, die het liever zonder indicatieve planning doet, en uitsluitend op zijn intuïtie vertrouwt. Plan of geen plan, de toekomstdimensie moet in de besluitvorming worden betrokken. Men krijgt de toekomst niet onder de knie door er - vanwege de vele onzekerheden - de ogen voor te sluiten, of het hoofd voor in het zand te steken. Dat geldt niet alleen voor de ondernemer, het geldt ook voor de overheid. Het is mijns inziens te betreuren - zoals ik dat ook in mijn boek heb opgemerkt1 ${ }^{2}$ - dat de 'N.V. Nederland' de operationele meerjarenplanning als politiek-committerend referentie- en beleidskader losliet in de jaren waarin de planning in het bedrijfsleven - zij het met vallen en opstaan, maar langs professionele weg - tot volle ontwikkeling kwam. Hoe gebrekkig en onzeker ook, de manager in een markteconomie, die het resultaat van zijn dagelijks werk niet afzet tegen een indicatief plan, is zich onvoldoende van de toekomstdimensie van zijn beslissingen bewust; hij maakt zijn medewerkers onvoldoende toekomstbewust en toekomstgericht, en onthoudt hen (en zichzelf) het houvast - hoe gebrekkig ook - waarop samenwerkende mensen elkaar kunnen aanspreken. Een goed operationeel jaarplan (dat volgens een vaste methodiek ieder jaar opnieuw - bijna gelijktijdig - 'topdown' en 'bottom-up' ontstaat) is voor het modeme management een onmisbare 'overeenkomst' tussen leiding en medewerkers.

De wijze waarop het kabinet-Lubbers onder andere de terugdringing van het financieringstekort van de overheid en van de collectieve uitgaven - maar ook een aantal andere probleemgebieden - heeft aangepakt is een voorbeeld van (welhaast) professionele meerjarenplanning die - ondanks alle verzet en kritiek vanuit de samenleving - voor het herstel van de Nederlandse economie van wezenlijke betekenis zal blijken te zijn.

Men versta mij niet verkeerd. Ook naar mijn mening zijn de mogelijkheden van indicatieve planning in een markteconomie beperkt, en moeten de eigen aard en grenzen goed in het oog worden gehouden, zoals ik in mijn boek uitvoeriger heb aangegeven13. En er kan (en zal) in een markteconomie altijd weer 'roet in het eten worden gegooid'14. De titel van een onlangs verschenen verzamelbundel Het moet, het kan! Op voor het plan! 15, werd danook niet door mij bedacht. Maar wel vind ik, dat een bewuste, systematische en professionele planning van het economisch beleid een eis van modern, doelmatig, management is; niet alleen in de onderneming, maar ook in de sfeer van de overheid.

Tegenover datgene wat in mijn herinnering aan indrukken uit de jaren vijftig aanwezig is, doet het beeld dat de historicus Griffiths oproept mij bloedeloos, mager, en hier en daar zelfs een beetje zuur en bijna rancuneus aan. Hij slaagt er maar zeer ten dele in de werkelijkheid van de eerste jaren na de oorlog tot leven te brengen. Voor een breed gefundeerd historisch-wetenschappelijk oordeel is naar mijn mening meer nodig dan de, op zichzelf nuttige en verhelderende cijferexercities van Griffiths.

Allereerst moet daarvoor een diepgaand onderzoek plaatsvinden naar de consistentie en de continuïteit van het gevoerde (materiële) economische beleid, dat uitging van de simpele gedachte: 'de markt waar mogelijk, de overheid waar nodig'; een onderzoek naar wat de historicus Johan de Vries het 'historisch constante' in onze economische geschiedenis heeft genoemd16.

Daarnaast is zeer veel archiefonderzoek nodig; met name naar de invloed van de inhoud en presentatie van het industrialisatiebeleid op het denken en doen van de duizenden deelnemers (ook toekomstige) aan het economisch besluitvormingsproces; archiefonderzoek bij de vakbewe-

12. Van den Brink, Zoeken naar een 'heilstaat', 325-327.

13. Ibidem,

14. Ibidem, 448 .

15. J. Jansen van Galen, e.a., Hel moet, het kan! Op voor het Plan! Vijftig jaar Plan van de Arbeid (Amsterdam, 1985).

16. Joh. de Vries, De Nederlandse economie tijdens de twintigste eeuw (Antwerpen-Utrecht, 1973) 115. 


\section{J.R.M. VAN DEN BRINK}

ging, de werkgeversorganisaties, de belangrijkste ondernemingen, de politieke partijen, de (andere) departementen, enz.

Ook moet de inhoud worden onderzocht van opinievormer.de artikelen in de dag- en weekbladen van die tijd; in de vakpers - onder andere de financiële pers - en de wetenschappelijkeconomische periodieken; de Handelingen van de beide Kamers der Staten-Generaal en de verslagen van provinciale en gemeentebesturen, en van de Sociaal-Economische Raad. De jaarverslagen van grote ondernemingen, onder andere van de banken; het gesproken woord, dat via de radio en de (opkomende)televisie, het grote publiek bereikte; tot een onderzoek naar de inhoud van schoolkrantjes en de opstellen van scholieren toe. Alleen langs die weg is het mogelijk voor wie de jaren vijftig niet zelf beleefde, een gefundeerd antwoord te geven op de door Griffiths aan de orde gestelde problematiek. Bij dit onderzoek dient aandacht te worden geschonken aan de vraag, in hoeverre de materiële inhoud en de presentatie van het industrialisatiebeleid bevorderlijk waren voor het ontstaan van een 'groeizaam' ondernemingsklimaat, een soort 'kweekbed' voor positieve investeringsbeslissingen; een vruchtbare 'akker van vertrouwen' in de industriële toekomst van Nederland. En bij dit alles moet men bedenken, dat van de vanzelfsprekendheid waarmee Griffiths over de industriële expansie van de jaren vijftig spreekt, in 1948/1949 bij tijdgenoten geen sprake was. Vooral de PvdA maakte zich over het gebrek aan elan in de ondernemerswereld ernstige zorgen. Bij de behandeling van de begroting-1948 van economische zaken, spreekt Nederhorst er zijn twijfel over uit of de 'investeringsdrang' van de Nederlandse ondernemers wel voldoende is 17. Maar ook Huysmans zelf wijst in de memorie van antwoord bij deze begrotingsbehandeling op de fantasieloosheid van de Nederlandse ondernemers bij de keuze van nieuwe objecten'18. Vos vraagt in november 1949 - naast bevordering van het particuliere initiatief - danook de 'ontwikkeling van het eigen initiatief (van de overheid)'19. Ook wetenschappelijke waarnemers uit die dagen zijn zeer gereserveerd ${ }^{2} 0$.

Tegenover dit alles heeft Griffiths' analyse de 'eenvoud' en abstraherende werking — pretendeert zij het gezag - van een accountantsrapport; maar dan van één, uitgebracht op een gebied waar de bevindingen van de accountant van zeer betrekkelijke waarde zijn. Ik ben er danook van overtuigd, dat zijn oren zouden klapperen wanneer hij, bij een aantal multinationals, een soortgelijk onderzoek zou instellen — zoals hij voor mijn industrialisatienota's deed - naar de trefzekerheid van prognoses, operationele jaarplannen en - vooral - meerjarenplannen in tijden van grote verandering, zoals de eerste (1973) en de tweede (1979-1980) oliecrisis; waarbij ik de vrachtenmarkt, de scheepsbouw en de staalindustrie als terrein van onderzoek nog maar laat rusten. Toch heeft het management, ook in deze laatste bedrijfstakken, er geen ogenblik over gedacht de indicatieve planning als 'tooi of management' in een markteconomie op de schroothoop te gooien.

De Korea-crisis voltrok zich geheel in de tijd waarop de eerste industrialisatienota's betrekking hebben. Griffiths ziet over het hoofd dat deze periode, op tal van punten, grote overeenkomst met de tijd van de internationale 'prijzenrevolutie' van de jaren zeventig vertoont ${ }^{2} 1$.

Naar aanleiding van het hierboven verlangde omvangrijke (archießonderzoek zal men mij tegenwerpen, dat deze Sysifusarbeid onuitvoerbaar is. Ik durf het niet tegen te spreken en zal er in ieder geval niet aan beginnen. Maar als de zaken zo liggen, zou het dan toch geen aanbeveling verdienen, om aan het getuigenis van tijdgenoten en 'ooggetuigen' althans énige waarde toe te kennen?

17. Handelingen van de Staten-Generaal, Tweede Kamer, Verslag 298-536, 1947-1948, 1340.

18. Tot zijn leedwezen heeft Huysmans geconstateerd 'dat slechts aan een betrekkelijk klein aantal van de zeer vele vergunningaanvragen' (tot vestiging van een bedrijf) 'een dergelijk 'reëel' initiatief ten grondslag ligt... Vermeldenswaard is in dit verband het feit, dat de onderhavige initiatieven zich voornamelijk richten naar die bedrijfstakken, waarin reeds een voldoende of meer dan voldoende capaciteit bestaat...'. Memorie van Antwoord, Xe hoofdstuk van de rijksbegroting voor het dienstjaar 1948, ingezonden 29 december 1947, 9.

19. Handelingen van de Staten-Generaal, Tweede Kamer, Verslag 1948-1949, 431.

20. Van den Brink, Zoeken naar een 'heilstaat', 441.

21. Ibidem, 448-451. 
DISCUSSIE INDUSTRALISATIEPOLITIEK

'Van den Brink, de herindustrialisatiepolitiek en zelfs de industrialisatienota's waren allemaal Produkten van hun tijd. Hier te gemakkelijk aan voorbij gaan levert mythologie op, geen geschiedschrijving', zegt Griffiths tot besluit. Er zal best wat van waar zijn. Wie kijkt niet met een beetje nostalgie op vijf goede jaren uit zijn leven terug? Maar zou het ook zo kunnen zijn, dat de historicus Griffiths zélf een beetje een produkt van zijn tijd is? Hoewel ik niet zo ver zou willen gaan 7.jnn werk als louter mythologie af te doen. 


\section{Repliek}

\section{R.T. GRIFFITHS}

Ik zou Van den Brink graag willen bedanken voor zijn lange en doorwrochte reactie op mijn stuk. Op vele punten zijn wij het met elkaar eens, niettegenstaande het feit dat dat bij een vergelijking van beide teksten niet in eerste instantie blijkt. Mij was slechts gevraagd commentaar te leveren op het historisch gedeelte van Zoeken naar een 'heilstaat' en daarom heb ik me geconcentreerd op de naoorlogse periode, een periode waarin Van den Brink zelf toevallig minister van economische zaken was. In zijn verhaal heb ik een tendens geconstateerd om onevenredig veel aandacht te besteden aan de industrialisatienota's, een tendens die ook in de overige historische literatuur aanwezig is. Ik heb geprobeerd deze tendens om te buigen door te wijzen op de tekortkomingen van deze benadering. Het was nooit mijn bedoeling mijn eigen visie op deze jaren en gebeurtenissen te presenteren en daarom is het niet verwonderlijk dat mijn artikel droog en eenzijdig blijkt te zijn.

Ik denk dat het grootste verschil tussen Van den Brink en mijzelf gelegen is in het feit dat ik, in tegenstelling tot Van den Brink, zeer sceptisch sta tegenover de waarde van indicatieve planning. Ten tweede zou ik veel meer nadruk willen leggen op het beleid achter die plannen, terwijl Van den Brink beleid en planning ziet als zaken, die elkaar aanvullen. Het probleem met Zoeken naar een 'heilstaat' is dat de planning het leeuwedeel van de aandacht krijgt, terwijl het beleid nauwelijks aan bod komt. Dat is mijns inziens jammer, angezien ik Van den Brinks rol met betrekking tot het doordrukken van de 'investeringsboom' bewonder. Als Van den Brink zijn verhaal vanaf de beleidskant had geschreven, dan zou hij misschien begonnen zijn met het late voorjaar of de vroege zomer van 1948 toen hij, tegen de wil van Lieftinck in, erin slaagde het kabinet de eerste uitgave voor het electrificatieplan te laten goedkeuren. Misschien zou hij dan de strijd binnen het kabinet om de Marshallhulp volledig te besteden, hebben beschreven, een strijd weer met Lieftinck, die meende dat een dergelijk beleid inflatoir was. Hij had dan ook aandacht kunnen besteden aan de merkwaardige verhouding binnen het kabinet, dat juist PvdAminister Sicco Mansholt zijn eigen beleid het trouwst steunde. Dan had hij wellicht de reële distributie van de Marshallhulp en andere kapitaaluitgaven van de regering beschreven en gerelateerd aan de structurele verandering van de economie. Want al deze zaken zijn mijns inziens belangrijk, belangrijker dan de beknopte presentatie van de hoofdpunten van het beleid en de 'twijfelachtige' voorspellingen van de industrialisatienota's.

De nieuwe informatie, die Van den Brinks artikel verschaft, is mijns inziens zeer interessant en heeft mij geboeid, maar ik denk nog steeds dat hij zijn eigen reputatie als minister tekort doet, evenals zijn reputatie als historicus. 
C.J.J.A. Morsch, Met de moed van de hoop. Studies over de vernieuwing van opvoeding, onderwijs en maatschappij in Nederland in de periode tussen \pm 1930 en 1984 (Dissertatie Nijmegen; Eindhoven: Grève offsett bv, 1984, x + 457 blz., ISBN 909000781 4, verkrijgbaar via de auteur, Van Heemstralaan 84, 6814 KL Arnhem).

Weinig instituties zijn in Nederland zo succesvol geweest als het onderwijs. Al vroeg in de negentiende eeuw gingen zeer veel kinderen naar de lagere school; vroeg in de twintigste eeuw zou ook het secundair onderwijs spectaculair stijgen (7,9\% van de bevolking van 12-19 jaar zat in 1900 op school; in 1950 was dat 45,1\%, in 1960 al 63,5\%). De bedragen aan het onderwijs ter beschikking gesteld, zouden stijgen van niet zeer veel tot ruim een kwart van de begroting.

Des te merkwaardiger is de grote ontevredenheid over het onderwijs: geen enkel auteur is er aan te treffen, die beweert dat het onderwijs aardig in elkaar steekt of dat het een redelijke intellectuele en sociale vorming biedt. Integendeel, nauw verbonden aan de groei van het onderwijs, nam ook de kritiek toe. Dit leidde ertoe, dat schrijven over onderwijs bijna altijd neerkwam op pleiten voor verandering. Er is een permanente belangstelling voor verschillende voorstellen tot vernieuwing van de school en het onderwijs: Montessori, Jenaplan, Dalton, Vrije School etc...

Opmerkelijk is dat al deze voorstellen op voorhand positief worden ontvangen: van nauwgezette onderlinge vergelijking of systematische en kritische analyse is tot voor kort nauwelijks sprake. In dat opzicht valt een vergelijking te trekken met wasmiddelen: veel reclame, waarbij meer nadruk wordt gelegd op het 'nieuw' op de verpakking dan een oordeel over de relatie tussen prijs en waskracht.

In de bundel Vernieuwingsstreven binnen het Nederlandse onderwijs in de periode 1900-1940 (Groningen, 1970) is al vastgesteld, dat het effect van al deze voorstellen op de praktijk niet zeer groot is geweest. Een conclusie die ook voor een latere periode geldig is. Zo vormt de onderwijsgeschiedenis van Nederland in de twintigste eeuw een intrigerende paradox: enerzijds een spectaculaire groei, verbonden met een sterke kritiek op organisatie en inhoud van het onderwijs, anderzijds een overvloedige aandacht voor 'vernieuwing' in tal van bladen, conferenties en moeitevolle experimenten, die nagenoeg niets hebben opgeleverd.

Deze uitvoerige introductie diende om het kader te schetsen, waarin het onderwerp van deze dissertatie gezien moet worden. Deze handelt over de IVO-beweging (Individueel Voortgezet Onderwijs). In het eerste hoofdstuk worden vier pioniers van dit onderwijs geschetst: J.H. Bolt, C. (Kees) Boeke, L.H. Fontein en J.R. Janssen. Vervolgens wordt dan dit onderwijs beschreven. Een derde hoofdstuk gaat over de Werkgemeenschap voor Vernieuwing van Opvoeding en Onderwijs (en Maatschappij), kortweg de WVO, in 1935 vooral door Boeke opgericht als denktank, sinds 1958 onder leiding van Leon van Gelder (de vader van de middenschool). In een vijfde hoofdstuk wordt tenslotte het tijdschrift van de WVO geanalyseerd. Een mooi programma; maar in welke mate is een bijdrage geleverd aan de hierboven geschetste paradox of, bescheidener, wordt inzicht gegeven in de aangesneden onderwerpen.

Een eerste probleem is de geringe kwantitatieve betekenis van dit onderwijs: vóór de oorlog bestond de IVO-beweging uit zes scholen: een zekere groei in de jaren zestig werd deels afgebroken door, deels geïncorporeerd in de mammoetwet. Des te belangrijker zou het zijn geweest de kwalitatieve betekenis van dit onderwijs te laten zien, maar dat is helaas niet gebeurd. De auteur geeft een uitvoerige lijst klachten over het 'traditionele' onderwijs (195 vlg.), vermeldt op diverse plekken dat het IVO het kind centraal stelde, maar maakt nergens duidelijk wat dat betekent (tenzij de intenties van schoolleiders worden gelijkgesteld met de praktijk). Zo meldt hij enigszins bedroefd het algemene vooroordeel tegen het IVO: 'standenscholen voor zogenaamde 'kneusjes" (149), maar doet geen poging dat te weerleggen. In het algemeen overigens ontbreekt een historisch-sociologische plaatsbepaling van dit onderwijs (dat zijn centrum had in het Gooi en Bloemendaal). Ook de WVO treft een dergelijke tekortschietende behandeling. Op gelijkmatige toon worden de verstandige én halfgare (theosofische) achtergronden van onderwijsvernieuwers in de jaren dertig bijeengezet. Alle idealen leidden tot weinig: gemiddeld 600 leden, geen krediet bij de overheid nà 1945, 'een conferentieoord zonder actiepro- 